\title{
Principles and Practices of Food Safety for Vegetable Production in Florida ${ }^{1}$
}

\section{Amy Simonne ${ }^{2}$}

According to the Centers for Disease Control and Prevention (CDC), in the 1990s up to 12\% of reported foodborne illness outbreaks were linked to fresh produce. Foodborne illness is a result of contamination by harmful substances or disease-causing microorganisms on food such as fresh produce. These contaminants are classified into three categories: biological (bacteria, virus, and parasite), chemical, and physical agents. Based on the current CDC data, $90 \%$ of foodborne illnesses come from biological agents. Many produce operations and farms have gone out of business after foodborne illness outbreaks were traced back to them. Foodborne illnesses can result in litigation and regulatory actions that may bring financial hardship to growers and producers. Furthermore, many major retail outlets now require their produce suppliers to document their food safety practices by means of certification or documentation. Growers of fresh produce need to keep food safety considerations in mind for their operations.

\section{Understanding Food Safety}

The microbial population of field-grown produce can be expected to reflect that of the environment in which it is grown. Although the majority of microorganisms found in the produce-growing environment are not disease-causing organisms, a few are of potential concern for the fresh produce industry (see Table 1 on next page). These disease-causing microorganisms can spread from their natural reservoirs and environments to humans, produce, and other hosts in a complex manner, as illustrated here.

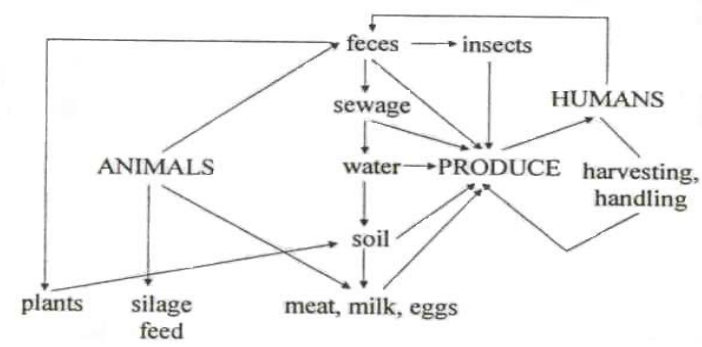

Figure 1. A diagram of how biological agents can come in contact with fresh produce. (From Beuchat 1996; reprinted with permission from Journal of Food Protection. Copyright held by the International Association for Food Protection, Des Moines, IA.)
Although produce is considered a lower risk compared to foods of animal origin, the risk of foodborne illnesses from fresh produce is real. Many microorganisms or chemicals have been implicated repeatedly as causative agents for foodborne illness outbreaks in fresh produce. Table 2 shows selected confirmed multiple outbreaks of foodborne illness associated with fresh produce since the 1990s. It is important that fresh produce is grown and handled to reduce potential points of contamination.

Table 2

\begin{tabular}{|l|l|}
\hline \multicolumn{1}{|c|}{ Produce } & \multicolumn{1}{c|}{ Pathogens/chemical } \\
Cantaloupe & $\begin{array}{l}\text { Salmonella spp./ E. coli } \\
\text { O157:H7 }\end{array}$ \\
\hline Raspberries & Cyclospora cayatenensis \\
\hline Tomatoes & Salmonella spp. \\
\hline Basil & Cyclospora cayatenensis \\
\hline Parsley & Shigella spp. \\
\hline $\begin{array}{l}\text { Green } \\
\text { onions/scallions }\end{array}$ & $\begin{array}{l}\text { Hepatitis A virus, Shigella } \\
\text { spp. }\end{array}$ \\
\hline Various berries & Cyclospora cayatenensis \\
\hline Lettuce & E. coli O157:H7 \\
\hline Cabbage & L. monocytogenes \\
\hline Watermelon & Salmonella spp./ Aldicarb \\
\hline
\end{tabular}

1. This publication is FCS8817, one of a series of the Department of Family, Youth and Community Sciences, Florida Cooperative Extension Service, Institute of Food and Agricultural Sciences, University of Florida. First published: November 2006. Please visit the EDIS Web site at http://edis.ifas.ufl.edu

2. Amy Simonne, Ph.D., associate professor, Department of Family, Youth, and Community Sciences, Institute of Food and Agricultural Sciences, University of Florida, Gainesville FL 32611. The Vegetable Production Handbook for Florida is edited by S.M. Olson, professor, NFREC-Quincy, and E.H. Simonne, associate professor, Horticultural Sciences Department, Institute of Food and Agricultural Sciences, University of Florida. 
Table 1: Disease-causing microorganisms of potential concern in fresh produce.

\begin{tabular}{|c|c|c|c|}
\hline \multicolumn{4}{|c|}{ Human-Disease-Causing Organisms } \\
\hline Categories & Names & Typical Natural Reservoirs & $\begin{array}{l}\text { Fresh produce susceptible to } \\
\text { contamination, or the produce } \\
\text { that microbes were isolated from }\end{array}$ \\
\hline \multirow[t]{10}{*}{ Bacteria } & Aeromonas hydrophilla & $\begin{array}{l}\text { Water (fresh, stagnant, } \\
\text { estuarine, or brackish water) }\end{array}$ & $\begin{array}{l}\text { Asparagus, broccoli, cauliflower, } \\
\text { celery, lettuce, pepper, spinach }\end{array}$ \\
\hline & Bacillus cereus & Soil and growing plants & Vegetables \\
\hline & Campylobacter jejuni & $\begin{array}{l}\text { Rabbits, rodents, wild birds, } \\
\text { sheep, horses, cows, pigs, } \\
\text { poultry, water, water supplies }\end{array}$ & $\begin{array}{l}\text { Green onions, lettuce, mushroom, } \\
\text { potato, parsley, pepper, spinach }\end{array}$ \\
\hline & Clostridium botulinum & $\begin{array}{l}\text { Environment, soils, and } \\
\text { sediments }\end{array}$ & Cabbage, mushrooms, peppers \\
\hline & E.coli O157:H7 & $\begin{array}{l}\text { Animal (cattle, deer)/human } \\
\text { feces, environment }\end{array}$ & Cabbage, celery, cilantro, coriander \\
\hline & Listeria monocytogenes & $\begin{array}{l}\text { Environment, soil, water, } \\
\text { aqueous environment, animal } \\
\text { and human feces }\end{array}$ & $\begin{array}{l}\text { Cabbage, chicory, cucumber, } \\
\text { eggplant, lettuce, mushrooms, } \\
\text { potatoes, radishes, salad vegetables, } \\
\text { tomato }\end{array}$ \\
\hline & Salmonella & $\begin{array}{l}\text { Natural environment, land and } \\
\text { aquatic animals }\end{array}$ & $\begin{array}{l}\text { Artichokes, celery, beet leaves, } \\
\text { cabbage, cantaloupe, cauliflower, } \\
\text { chilis, cilantro, eggplant, endive, } \\
\text { fennel, green onions, lettuce, parsley, } \\
\text { peppers, salad greens, spinach, } \\
\text { strawberries, tomatoes, watermelon }\end{array}$ \\
\hline & Shigella & Humans, monkeys & $\begin{array}{l}\text { Celery, cantaloupe, lettuce, parsley, } \\
\text { scallions }\end{array}$ \\
\hline & Staphylococcus & Humans, animals & Carrots, lettuce, parsley, radishes \\
\hline & Vibrio cholerae & $\begin{array}{l}\text { Environment, humans, and } \\
\text { animals }\end{array}$ & Cabbage, lettuce \\
\hline Viruses & $\begin{array}{l}\text { Hepatitis A and E, } \\
\text { norovirus }\end{array}$ & Water, environment & $\begin{array}{l}\text { Green onions, strawberry, tomatoes, } \\
\text { celery }\end{array}$ \\
\hline $\begin{array}{l}\text { Protozoan } \\
\text { parasites }\end{array}$ & $\begin{array}{l}\text { Cryptosporidium, } \\
\text { Cyclospora, Giardia, } \\
\text { Toxoplasma }\end{array}$ & $\begin{array}{l}\text { Feces of animals and humans, } \\
\text { water, sewage }\end{array}$ & $\begin{array}{l}\text { Basil, raspberries, blackberries, } \\
\text { lettuce, raw vegetables, lettuce, } \\
\text { onions, tomatoes }\end{array}$ \\
\hline
\end{tabular}

It is difficult to determine the exact source of contamination of human pathogens on fresh produce, because at any point throughout production, harvesting, and handling, the diseasecausing microorganisms can come in contact with produce by various means. General sanitation practices are very important to reduce the spread of diseases and to prevent the possibility of contamination with human pathogens. The FDA Guide to Minimize Microbial Food Safety Hazards for Fresh Fruits and Vegetables recommends simple food safety principles for producers to follow.

\section{Principle 1: Preventing contamination}

Prevention of microbial/chemical contamination of fresh produce is better than relying on corrective actions once contamination has occurred. Producers can reduce the risk of contamination by checking the land use history for both potential microbial and chemical

contamination. Depending on the microbe and the environmental conditions, some types of diseasecausing microbes can survive for several months. Because grazing animals on or near cropland can introduce disease-causing bacteria to the soil, and because, once introduced, the disease-causing agents can survive for many months, growers should ensure that the land has not been used for animal husbandry and that it is not in proximity to 
animal feedlots or water runoff from grazing lands. Past improper use or disposal of pesticides/other chemical wastes can result in hazardous residues being absorbed by produce. If in doubt about the land, determine soil residue levels of pesticides and heavy metals before planting.

\section{Principle 2: Minimizing contamination}

To minimize microbial/chemical food safety hazards in fresh produce, producers and others involved in production should use good agricultural and management practices in those areas over which they have control. These include water quality, surrounding land use, irrigation and fertilization practices, and worker health and hygiene. Agricultural water is frequently a shared resource. While growers may not have control over factors that affect the watershed, awareness of potential problems helps determine which control options are most appropriate. In assessing water quality, operators should consider what affects their portion of the watershed. Growers may consider prevalence of animal production in the region, manure use on land by farms in the region, the impact of local rainfall patterns and topography on the likelihood of contaminated runoff from these operations reaching surface waters, and control measures that are in place from other farm or animal operations. Good Agricultural Practice (GAPs) for some specific crops can be found at http://edis.ifas.ufl.edu/FS093 and http://edis.ifas.ufl.edu/FS094.

\section{Principle 3: Minimizing contacts from human or animal feces}

The major sources of disease-causing microbes are human or animal feces. If producers have poor management of animal, human, and other wastes, the chance of fecal materials coming in contact with fresh produce increases.

- Workers must have access to sanitary facilities in the field (see Principle 6).

- Exclude farm or domestic animals from all fresh produce production to prevent the likelihood of significant amounts of uncontrolled deposits of animal feces coming into contact with produce by using proper physical barriers as well as other management systems.

- The presence of wild animals (deer, hogs, or waterfowl) may increase the chances of contamination, and the producer must plan their fields accordingly to reduce the risk. Where high concentrations of wildlife are a concern, consider practices to deter or redirect wildlife to areas where crops are not destined for fresh produce markets

- Where necessary and possible, consider physical barriers from wildlife, such as fences, ditches, mounds, grass/sod waterways, diversion berms, and vegetative buffer areas.

\section{Principle 4: Ensuring a safe water supply}

Whenever water comes in contact with produce, its source and quality are directly linked to the potential for contamination. Producers must minimize the potential for microbial contamination from water used with fresh fruits and vegetables by using clean water. Typical sources of agricultural water include surface water, groundwater, and municipal supplies.

- Groundwater is generally less likely to be contaminated with high levels of pathogens than surface water. However, under certain conditions, such as shallow wells or improperly constructed or older wells, the groundwater may be under the influence of surface water, and thus more susceptible to contamination.

- Producers should first concentrate on protecting and maintaining water quality. However, where water quality is unknown or cannot be controlled, growers may want to consider irrigation practices that minimize contact between water and the edible portion of the crop.

- Overhead irrigation is more likely to spread contamination to aboveground plant parts than is root-zone irrigation.

- Water used for frost protection of crops to be consumed fresh, such as strawberries, should be of drinking-water quality.

- Water quality information can be obtained from the local water authority. Growers can consult local water quality experts, such as 
state or local environmental protection or public health agencies, Extension agents or land grant universities (see

http://edis.ifas.ufl.edu/ and http://edis.ifas.ufl.edu/pdffiles/FE/FE04700.p df), for advice appropriate for individual operations.

- For producers using groundwater for irrigation: more information on wellhead protection in Florida can be found at http://www.dep.state.fl.us/water/groundwater/ wellhead.htm.

\section{Principle 5: Using manure and municipal biosolids safely}

Incompletely composted organic fertilizers may contain disease-causing microorganisms from animal or human feces. Research reveals that the disease-causing microorganisms from raw manure can persist in the soil for a long period of time, depending on environmental conditions.

- If organic fertilizers are used, they must be certified that they have been completely composted so pathogens are not present.

- Inorganic fertilizers originate from nontoxic, synthetic chemicals, so no pathogens are present.

- Composted sewage sludge may contain pathogens as well as heavy metal contamination. Federal regulations address the requirements for use of biosolids in the U.S. Consult the Florida EPA for the latest requirements on the use of biosolids: http://www.dep.state.fl.us/.

- Do not use raw manure or leachate from raw manure during the growing season.

- Producers may obtain guidance on proper agronomic methods for the use of biosolids from The USDA's Natural Resources Conservation Service (NRCS) (formerly the Soil Conservation Service), and the FDA Good Agricultural Practice (FDA, 1998). Specific information on the application of manure in organic production can also be found at http://edis.ifas.ufl.edu/HS217.
Principle 6: Focusing on worker health and hygiene

There is a direct correlation between poor personal hygiene and foodborne illness. Worker health and hygiene and good sanitation practices during production, harvesting, sorting, packing, and transport are critical in minimizing the potential for microbial contamination of fresh produce. Exclude employees with symptoms such as vomiting, diarrhea, fever, sore throat, and jaundice (look for yellow eyes or skin) from contact with fresh produce.

- Training. Training and orientation for workers on the basic principles of health and hygiene, handwashing techniques, and recognizing foodborne illness symptoms can help them understand their role in disease prevention.

- Adequate handwashing stations. An adequate number [one facility is required for every 20 employees (FDA GAPs)] of handwashing units should be available. They should be fully stocked and easily accessible, and no more than a five-minute walk (in the field) from where any employee is working. Instructions for proper use of the handwashing unit should be prominently posted.

- Toilet facilities in the field. An adequate number of toilet facilities with handwashing units should be available. One facility is required for every 20 employees (FDA GAPs). Facilities should be fully stocked, easily accessible, and no more than a fiveminute walk from where any employee is working. Instructions for proper use should be prominently posted.

- Employee accommodations. Provide a clean area for employees to eat, drink, and use tobacco.

Producers can obtain additional information, such as training videos in both English and Spanish, from http://www.ifasbooks.ufl.edu/merchant2/. At the EDIS search screen, type in "worker health." A training manual is also available at http://edis.ifas.ufl.edu/FY743. An explanation of how to document worker training is available at http://edis.ifas.ufl.edu/FY716. 


\section{Principle 7: Following the law}

Follow all applicable local, state, and federal laws and regulations. For export markets, producers may need to consult other standards for operators outside the U.S.; see http://www.flworkshop.com/.

\section{Principle 8: Being accountable}

Accountability at all levels of the agricultural environment (farm, packing facility, distribution center, and transport operation) is important to a successful food safety program. There must be qualified personnel and effective monitoring to ensure that all elements of the program function correctly and to help track produce back through the distribution channels to the producer. Growers must keep good records, and document all training.

\section{Getting Started on a Food Safety Program at Your Farm}

To obtain additional information on specific topics of farm food safety or training on GAPs, contact your local County Extension agricultural agents. In addition, resources on farm food safety can be obtained from the Web sites of the FDA (http://www.cfsan.fda.gov/), the USDA (http://www.nps.ars.usda.gov/), and the EPA (http://www.epa.gov/pesticides/food ). A summary of existing farm food safety programs around the world can be found at http://www.foodsafetynetwork.ca/articles/365/on_ farm_fd_sfty_fruit-veggie.pdf.

\section{References}

Beuchat, L. R. 1996. Pathogenic microorganisms associated with fresh produce. J. Food Prot. 59:204-216.

Ferguson, J.J. and M. R. Ziegler. Guidelines for purchase and application of poultry manure for organic crop productions.

http://edis.ifas.ufl.edu/HS217.

Holmes-Pearce, M., M. Ritenour, A. Simonne, J. Brecht, S. Sargent, and K. Schneider. Good worker health and hygiene practices: Evaluation and importance in GAPs and GMPs.

http://edis.ifas.ufl.edu/FY716.
Mahovic, M., J.K. Brecht, S.A. Sargent, M.A. Ritenour, K.R. Schneider, A. Simonne, and J. Bartz. Fresh produce handling, sanitation, and safety measures: strawberry, raspberry, blackberry, and blueberry. http://edis.ifas.ufl.edu/FS093.

Mahovic, M., J.K. Brecht, S.A. Sargent, M.A. Ritenour, K.R. Schneider, A. Simonne and J. Bartz. Fresh produce handling, sanitation, and safety measures: Beans, cucumbers, eggplants, squash, pepper, sweetcorn. http://edis.ifas.ufl.edu/FS094.

Mead, P.S., L. Slutsker, V. Dietz, L.F. McCaig, J.S. Bresee, C. Shapiro, P.M. Griffin, and R.V. Tauxe. 1999. Food-related illnesses and death in the United States. Emerging Infect. Dis. 5:607625.

Simonne, A., J. Brecht, S. Sargent, M. Ritenour, and K. R. Schneider. Good worker health and hygiene practices: Training manual for produce handlers. http://edis.ifas.ufl.edu/FY743.

Sivapalasingam, S., C.R. Frieman, L. Cohen, and R.V. Tauxe. 2004. Fresh produce: A growing cause of outbreaks of foodborne illness in the United States, 1973-1997. J. Food Prot. 67(10):2342-2353.

United States Food and Drug Administration. 1998. Guide to minimize microbial food safety hazards for fresh fruits and vegetables. FDA/CFSAN Web site. http://www.cfsan.fda.gov/ dms/prodglan.html.

\section{Additional Resources}

International Fresh-Cut Produce Association, Produce Marketing Association, United Fresh Fruit and Vegetable Association, Western Growers Association. 2006. Commodity specific food safety guidelines for the lettuce and leafy greens supply chain.

http://www.cfsan.fda.gov/ acrobat/lettsup.pdf\#sea rch=\%22Commodity $\% 20$ specific\%20guidelines $\%$

The North American Tomato Trade Work Group. 2006. Commodity specific food safety guidelines for the fresh tomato supply chain. http://www.cfsan.fda.gov/ dms/tomatsup.html. 
Produce Marketing Association, United Fresh

Fruit and Vegetable Association. 2005.

Commodity specific food safety guidelines for the melon supply chain.

http://www.uffva.org/PDF/MelonCommoditySpec

ific.pdf\#search=\%22Commodity $\% 20$ specific $\% 20$ guidelines $\% 22$.

United States Environmental Protection Agency. Drinking water priority rulemaking: Microbial and disinfection byproduct rules. EPA Web site. http://www.epa.gov/OGWDW/mdbp/mdbp.html.

United States Food and Drug Association. 2004. Produce safety from production to consumption: 2004 action plan to minimize foodborne illness associated with fresh produce consumption.

FDA/CFSAN Web site.

http://www.cfsan.fda.gov/ dms/prodpla2.html. 


\begin{tabular}{|c|c|c|c|}
\hline \multicolumn{4}{|c|}{ Checklist for potential hazards that can be controlled } \\
\hline Items & Potential Hazard & Preventive measure & Documentation \\
\hline \multirow[t]{2}{*}{ Land } & $\begin{array}{l}\text { Chemical } \\
\text { residue/pesticides in soil }\end{array}$ & Review land history & Certification/documentation \\
\hline & $\begin{array}{l}\text { Potential contamination } \\
\text { of animal/human wastes }\end{array}$ & $\begin{array}{l}\text { No animal farm near } \\
\text { production land }\end{array}$ & Certification/documentation \\
\hline \multirow[t]{2}{*}{ Fertilizers } & Disease-causing agents & $\begin{array}{l}\text { Use inorganic fertilizer or use } \\
\text { composted organic fertilizers }\end{array}$ & Official test results \\
\hline & $\begin{array}{l}\text { Heavy metal from } \\
\text { sewage sludge }\end{array}$ & Use certified organic fertilizers & Official test results \\
\hline Pesticide use & Illegal levels of residue & $\begin{array}{l}\text { Use only licensed } \\
\text { applicator/monitoring program }\end{array}$ & $\begin{array}{l}\text { Examine applicator records } \\
\text { Keep application records as } \\
\text { required by law }\end{array}$ \\
\hline $\begin{array}{l}\text { Irrigation water } \\
\text { Surface water }\end{array}$ & Disease-causing agents & $\begin{array}{l}\text { a) Monitor water quality } \\
\text { b) Use subirrigation or drip or } \\
\text { system that minimizes contact } \\
\text { of water with edible portion of } \\
\text { the produce }\end{array}$ & Water test result \\
\hline $\begin{array}{l}\text { Irrigation water } \\
\text { Groundwater }\end{array}$ & Disease-causing agents & $\begin{array}{l}\text { a) Monitor water quality } \\
\text { b) Protect wellhead } \\
\text { b) Use subirrigation or drip or } \\
\text { system that minimizes contact } \\
\text { of water with edible portion of } \\
\text { the produce }\end{array}$ & Document water quality \\
\hline $\begin{array}{l}\text { Frost protection } \\
\text { water }\end{array}$ & Disease causing agents & $\begin{array}{l}\text { a) Use known quality water } \\
\text { b) Use municipal water }\end{array}$ & Document water quality \\
\hline Hand harvest & $\begin{array}{l}\text { Contamination by } \\
\text { disease causing agents } \\
\text { from workers }\end{array}$ & $\begin{array}{l}\text { a) Train workers } \\
\text { b) Provide sanitary facility }\end{array}$ & Document worker training \\
\hline Field containers & $\begin{array}{l}\text { Soil, disease-causing } \\
\text { agents }\end{array}$ & $\begin{array}{l}\text { Use bins that can be cleaned } \\
\text { and/or disinfected and clean } \\
\text { regularly }\end{array}$ & $\begin{array}{l}\text { Keep record of field sanitation } \\
\text { measures }\end{array}$ \\
\hline
\end{tabular}

